\title{
RUMBAQU: RUMAH BACA AL QUR'AN SEBAGAI SOLUSI IDEAL TEMPAT BELAJAR BAGI ANAK DI ERA PANDEMI COVID-19.
}

\author{
Supriadi1), Rismawati ${ }^{2}$ \\ 1)Fakultas Teknik Informatika/Informatika Komputer, Universitas Cokroaminoto Palopo, Palopo, Sulawesi Selatan, \\ Indonesia \\ ${ }^{2)}$ Fakultas Ekonomi dan Bisnis/Akuntansi, Universitas Muhammadiyah Palopo, Palopo, Sulawesi Selatan, Indonesia
}

Corresponding author : Rismawati

E-mail : risma11@umpalopo.ac.id

\section{Diterima 28 Juli 2021, Direvisi 06 Agustus 2021, Disetujui 06 Agustus 2021}

\begin{abstract}
ABSTRAK
Pengabdian pada masyarakat ini di latarbelakangi oleh pandemi covid-19, dimana pola pendidikan anak berubah signifikan. Aktifitas belajar mengaji bagi anak perumahan Islamic centre permai tidak dapat lagi menggunakan teras tumah yang berukuran 6 (enam) meter persegi dengan jumlah santri 15 (lima belas) orang. Pengusul bersama warga berinisiasi membangun rumbaqu (rumah belajar Al-Qur'an) yang lebih luas. Di rumah belajar Al-Qur'an ini santri belajar iqro, tartil dan menulis. Metode iqro digunakan untuk memastikan pelafalan huruf hijaiyah telah sesuai, sedangkan metode Al-baghdadiyah digunakan untuk memastikan bacaan tajwid dan mahraj telah benar. Untuk aktivitas belajar menulis huruf hijaiyah dapat dinilai dari kerapian tulisan. Seluruh kegiatan belajar diakhiri dengan evaluasi. Pada metode iqro, dilakukan untuk memastikan bahwa santri dapat berpindah pada jenis huruf berikutnya, sedangkan pada metode Al-baghdadiyah untuk memastikan bacaan telah sesuai dengan tajwid dan mahraj sehingga tartil Al-Qur'an benar. Hadirnya rumbaqu menjadikan aktivitas belajar kembali dapat berjalan. Hasil pengabdian adalah terbangunnya rumbaqu dan meningkatnya kemampuan santri dalam membaca Al-Qur'an.
\end{abstract}

Key word: pandemi covid-19; rumbaqu; iqro', Al-baghdadiyah

\begin{abstract}
This community service is motivated by the COVID-19 pandemic, where the pattern of children's education has changed significantly. Qur'an learning activities for the children of the Islamic Center Indah housing complex can no longer use a 6 (six) square meter house terrace with a total of 15 (fifteen) students. The proposer and the residents took the initiative to build a wider "Rumbaqu". In this AI-Qur'an learning house, students learn "iqro'", "tartil", and "writing". The "lqro" method is used to ensure that the pronunciation of the "hijaiyah" letters is appropriate, while the "Al-Baghdadiyah" method is used to ensure that the "tajwid" and "mahraj" pronunciation are correct. For learning activities to write "hijaiyah" letters, it can be assessed from the neatness of writing. All learning activities end with an evaluation. The "lqro" method, is used to ensure that students can move on to the next type of letter, while in the "Al-Baghdadiyah" method is used to ensure that the "tajwid" and the "mahraj" of the "tartil" of the Qur'an is correct. The existenxe of the "Rumbaqu" makes learning activities work again. The expected outcome of the service is the development of "Rumbaqu" and the ability of students to read the Qur'an.
\end{abstract}

Keywords: covid-19 pandemic; rumbaqu; iqro', Al-baghdadiyah

\section{PENDAHULUAN}

Pandemi Covid-19 telah berlangsung

sejak tanggal 2 Maret 2020 (versi https://news.detik.com/). Seiring hal tersebut, tatanan kehidupan juga berubah. Berbagai aktivitas dilakukan di luar kebiasaan, salah satunya adalah aktifitas belajar. Peraturan Walikota (PERWALI) No. 10 tahun 2020 tentang Pedoman Pelaksanaan Tatanan Kebiasaan Baru pada Kondisi Pandemi Corona Virus Disease 2019 di Kota Palopo salah satunya tentang aturan agar tetap berada di dalam rumah (stay at home). Di Kota Palopo himbauan stay at home benar-benar dipatuhi selama dua bulan pertama. Setelahnya ada kejenuhan mengurung diri di dalam rumah. Satu-persatu warga mulai keluar dan beraktifitas seperti biasa. Anak-anak komplek perumahan Islamic Centre Permai (Perum ICP) Kota Palopo mulai ramai bermain di luar rumah. Diskusi seru para ibu perum ICP yang mulai over job dimana mereka harus menambah pekerjaan sebagai "guru pengganti" bagi anak-anaknya. Aktifitas belajar di sekolah ditiadakan diganti dengan aktivitas belajar di rumah secara daring. Keadaan yang baru 
terjadi sepanjang sejarah ini membuat masyarakat pada umumnya menjadi shock. Seluruh masyarakat "dipaksa" untuk melek teknologi.

Meskipun pendidikan keluarga adalah proses pendidikan awal sekaligus utama (Baharun, 2016), namun dari hasil diskusi dengan Ibu-ibu rumah tangga yang tidak siap menjadi guru bagi anak-anaknya adalah orang yang paling shock dengan keadaan ini. Dimana pekerjaan rumah yang tidak ada habisnya, saat pandemi Covid-19 melanda, pekerjaannya bertambah menjadi guru privat bagi anakanaknya. Menteri pendidkan Nadiem Makarim dalam bulletin IDN time news (https://kaltim.idntimes.com) menyebutkan salah satu dampak negative anak sekolah daring adalah anak semakin rentan mendapat kekerasan dalam rumah tangga yang tidak dapat dideteksi oleh guru. Ungkapan Nadiem disenada dengan artikel yang diterbitkan oleh Tempo (https://metro.tempo.com). Ada yang menjalaninya dengan santai karena profesi kesehariannya adalah pengajar, ada yang bingung hingga stress karena tidak pernah membayangkan betapa sulitnya memberikan pemahaman kepada anaknya. Alhasil, keadaan ini memaksa orang tua menjadi serba bisa.

Pemberlakuan sekolah daring menjadi sesuatu yang menggelisahkan (Cahyati \& Kusumah, 2020). Ibu-ibu rumah tangga yang selama ini hanya menggunakan handphone sebagai alat bersosial media, tiba-tiba harus menggunakannya sebagai media belajar bagi anak-anaknya (Satrianingrum \& Prasetyo, 2020). Tidak jarang suara keras sebagai bentuk pelampiasan ibu kepada anaknya yang susah diatur, susah diberi pemahaman, atau mungkin saja orang tuanya tidak mengerti apa yang diiginkan oleh soal-soal yang dikirim oleh sekolah. Dinamika ini semakin jelas dan kegelisahan warga menjadi kegelisahan kami.

Keadaan tidak selesai sampai di situ, satu beban yang sulit untuk diselesaikan adalah kemampuan anak untuk membaca Al-Qur'an. Lubis et al., (2020) mengatakan bahwa belajar Al-Qur'an memiliki keunikan sendiri, selain sehingga bagi anak-anak masih sangat sulit memahami jika harus belajar mengaji via daring. Masalah makin terasa jika kedua orang tua juga tidak bisa mengajar dengan benar.

Perum ICP tidak memiliki Taman Pendidikan Al Qur'an (TPA). Kami (penulis artikel ini) adalah sepasang suami-istri yang kebetulan memiliki profesi yang sama. Komplek perumahan tempat tinggal kami adalah komplek perumahan yang berjarak dengan komplek perumahan yang lain. Komplek Perumahan Islamic Centre Permai, ya begitulah nama resmi perumahan kami. Meskipun di Kota
Palopo nama perumahan ini belum familiar. Wajar saja karena jumlah unit rumah hanya 37 rumah itupun posisinya di tengah persawahan, sehingga perumahan ini tidak sepopuler perumahan-perumahan yang lain. 37 unit rumah ini yang berpenghuni baru sekitar 27 rumah. 27 kepala keluarga ini adalah keluarga muda dimana umur pernikahan masih di bawah 15 tahun, sehingga setiap rumah dapat dipastikan memiliki anak usia pendidikan Sekolah Dasar (data observasi lapangan).

Sebagai seorang dosen agama di Universitas Cokroaminoto Palopo saya tergerak untuk melakukan sesuatu untuk warga perumahan ini. Kami berdiskusi dan memutuskan untuk mengambil tanggung jawab sebagai Guru Mengaji bagi anak-anak di perumahan ini. Awalnya, kami memanfaatkan teras rumah, tetapi karena jumlah santri semakin banyak maka teras yang berukuran 3 x 2 meter itu tidak dapat menampung anakanak (santri). Karena tidak muat, maka santri bergilir untuk dapat duduk di teras rumah. Hal tersebut membuat mereka menjadi tidak bersemangat, karena tidak bisa bersama-sama, kemudian harus berhenti total ketika pandemi covid-19 melanda seluruh dunia.

Masa social distancing menjadikan kami berpikir keras untuk melaksanakan pengabdian kami kepada warga sebagai Guru mengaji. Dimana teras rumah sudah tidak memenuhi syarat untuk dijadikan tempat santri untuk belajar. Disatu sisi upaya menghidupkan Al-Qur'an dan menanamkannya pada anakanak menjadi impian kami.

Satu kesadaran yang sama dimana setiap orang tua pasti menginginkan buah hatinya menjadi anak yang shalih dan salihah. Salah satu yang wajib diajarakan kepada anak adalah segala hal tentang Al-Qur'an, karena AlQur'an merupakan pedoman hidup manusia. Mengajarkan Al-Qur'an kepada anak-anak merupakan untuk dekat dengan pedoman hidupnya dan selalu dekat dengan Allah. Rasulullah saw. Pernah bersabda: "Didiklah anak-anakmu dengan tiga perkara: mencintai Nabimu, mencintai ahlul baitnya dan membaca Al-Qur'an karena orang-orang yang memelihara Al-Qur'an itu berada dalam lingkungan singasana Allah pada hari ketika tidak ada perlindungan-Nya, mereka beserta para nabi-Nya dan orang-orang suci." (Ath Thabrani, 2009 p. 124). 


\section{METODE}

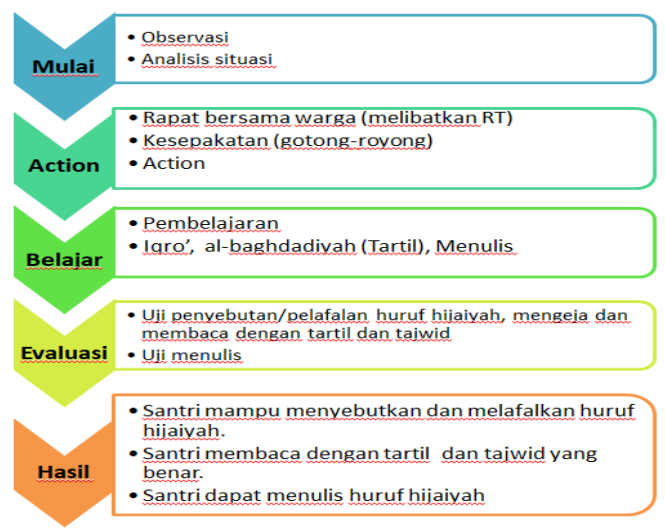

Gambar 1. Metode Pelaksanaan

Setelah permasalahan utama didiskusikan dengan warga maka kami meneruskan hasil diskusi tersebut kepada ketua RT. Selanjutnya, ketua RT mefasilitasi untuk melakukan rapat dan mengundang warga perumahan untuk melakukan urun rembug. Dalam acara urun rembug tersebut ditetapkan bahwa warga menginginkan adanya Rumah Baca Al Qur'an (Rumbaqu). Rumbaqu akan segera diwujudkan untuk kepentingan anakanak disekitar komplek perumahan. Rumbaqu didirikan di atas kolam ikan milik kami dan dikerjakan secara gotong royong oleh warga dengan dana bersumber dari kami.
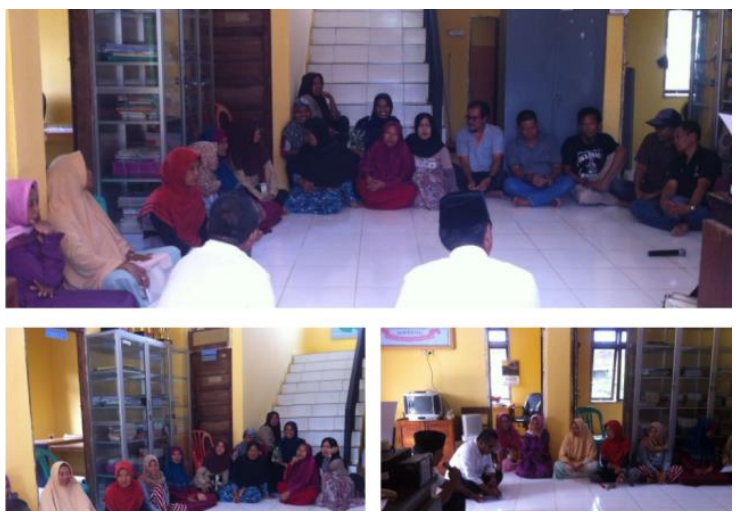

Gambar 2. Persiapan

\section{HASIL DAN PEMBAHASAN}

Rumbaqu didirikan dengan cara gotong-royong selama 3 hari. Dalam perjalanan pengerjaannya ada dua orang donator yang menyumbang dalam bentuk uang, hal tersebut sangat membantu. Berdirinya rumbaqu menjadi tempat kami mengabdikan diri kepada warga dan sebagai tempat untuk belajar Al-Qur'an, mulai dari iqro tartil dan menulis huruf hijaiyah. Hingga saat ini jumlah santri yang tercatat sebanyak 15 orang.

Rumbaqu adalah upaya menjaga generasi penerus dapat membaca Al-Qur'an merupakan usaha yang harus dilakukan secara terus menerus. Al-Qur'an merupakan materi utama yang sejatinya dididikkan pada anak. Mengapa demikian? sebab, Islam meyakini bahwa di dalamnya terdapat petunjuk dan pedoman kehidupan. Mempelajari Al-Qur'an diawali dengan mengenal huruf hijaiyah kemudian membaca dengan tartil merupakan implementasi dari ilmu membaca (Anjarsari et al., 2017) yang akan berlanjut dengan menghafal Al Qur'an adalah upaya untuk melestarikannya. Assingkily, (2019) menambahkan bahwa setelah mengetahui, proeses selanjutnya adalah memahami dan diakhiri dengan mengamalkan; ini adalah intisari dari prinsip kehidupan manusia pembelajar.

Upaya menghidupkan Al Qur'an atau living Qur'an, merupakan usaha yang dilakukan oleh individu, kelompok, organisasi atau masyarakat dalam menyikapi berbagai situasi untuk terus melestarikan kajian Al Qur'an di daerahnya, baik dalam aspek sosial, pendidikan, budaya, ritual peribadatan, dan lain sebagainya (Nurhidayah et al., 2019).

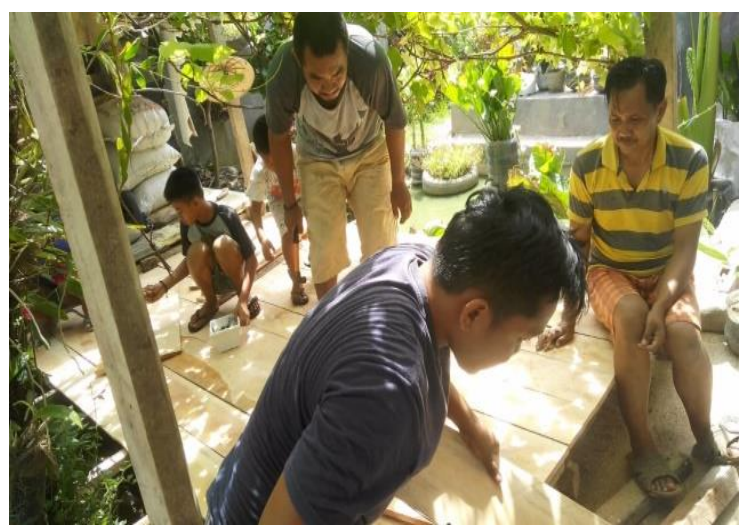

Gambar 3. Pelaksanaan

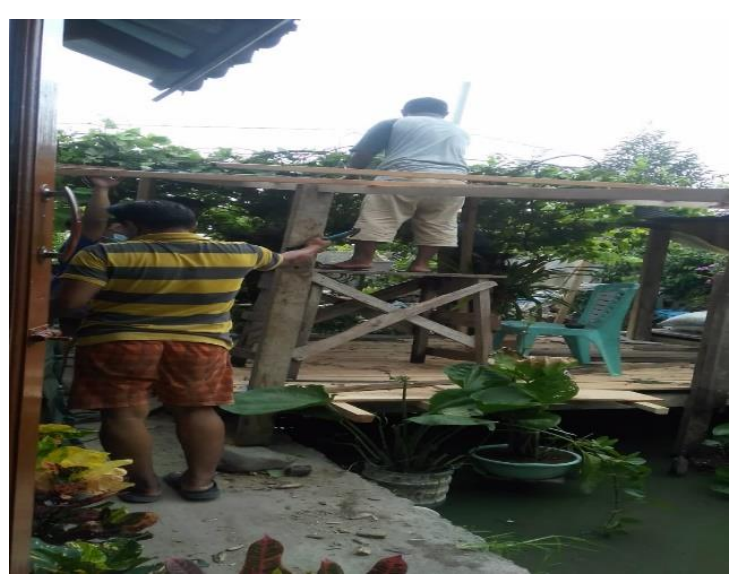

Gambar 4. Pelaksanaan

Di rumah belajar Al-Qur'an ini santri belajar membaca, menulis dan melafalkan dengan benar ayat-ayat Al-Qur'an. Untuk 
mencapai hal tersebut kami menggunakan dua metode yaitu metode iqro dan Al-baghdadiyah . Metode iqro digunakan untuk memastikan pelafalan huruf hijaiyah telah sesuai, sedangkan metode Al-baghdadiyah digunakan untuk memastikan bacaan tajwid dan mahraj telah benar. Pada metode iqro, dilakukan untuk memastikan bahwa santri dapat berpindah pada jenis huruf berikutnya, sedangkan pada metode Al-baghdadiyah untuk memastikan bacaan telah sesuai dengan tajwid dan mahraj sehingga tartil Al-Qur'an benar. Proses pembelajaran berjalan seiring dengan proses evaluasi, sehingga setiap hari santri dapat naik pada tahap berikiutnya. Untuk aktivitas belajar menulis huruf hijaiyah dapat dinilai dari kerapian tulisan. Seluruh kegiatan belajar diakhiri dengan evaluasi yang akan dicatat pada kartu kontrol santri.

Hasil penelitian yang dilakukan oleh Lubis et al., (2020) mengatakan bahwa pembelajaran Al-Qur'an, idealnya diberikan kepada anak sejak usia dasar. Hal ini ditujukan agar anak mampu memahami Al-Qur'an sejak dini dan menumbuhkan kecintaan anak terhadap Al-Qur'an. Oleh karena itu, pembelajaran Al-Qur'an tidak boleh berjeda apalagi berhenti diberikan pada anak dalam situasi dan kondisi apapun, termasuk era pandemi covid-19 yang mewabah di dunia. Pembelajaran Al-Qur'an era covid-19 dilaksanakan dengan berbagai cara oleh pendidik di masing-masing daerah. Hal ini didasari kearifan lokal yang berbeda, metode pembelajaran, tujuan dan sasaran pembelajaran yang hendak diterapkan oleh para pendidik.Dengan demikian, pembelajaran yang diberikan juga disesuaikan dengan daerah tertentu (Iqromah, 2018).

Kami menyadari sepenuhnya bahwa sejatinya, Al-Qur'an sebagai kalamullah mengandung makna mendalam yang patut ditelaah oleh umat manusia. Ibarat benih, Al Qur'an ditanamkan sejak usia dasar, hal ini agar mereka secara perlahan dapat menyerap ilmunya dan dapat menjadi bekal kehidupan dan "modal" mengenali Sang Khalik (Allah swt.) melalui ciptaan-Nya (Ulfah et al., 2019). Allah SWT. sebagai Sang Khalik (Maha Pencipta), juga dikenali oleh hamba-Nya dalam kehidupan ini melalui ciptaan-Nya di bumi dan di langit. Untuk itu, tadabbur alam menjadi keniscayaan yang dilakukan oleh setiap manusia. Sebelum itu, tentu memahami Al Qur'an sebagai pedoman hidup adalah hal prioritas (utama). Assingkily (2019) menyatakan bahwa al-Qur'an itu "hidup" dan umat manusia harus menghidupkan Al Qur'an dalam dirinya melalui perilaku yang terpuji dan mulia. Oleh karena itu, begitu banyak cara dan juga budaya yang berkembang di masyarakat dalam upaya menghidupkan Al Qur'an.

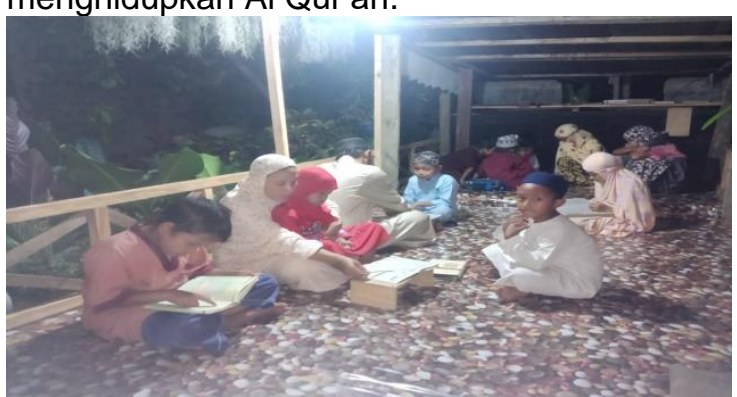

Gambar 5. Pelaksanaan dan Evaluasi

Menyambut hasil kajian di atas menguatkan ikhtiar kami untuk mengabdi di jalan ini, sebagai bagian dari upaya melestarikan Al Qur'an. Meskipun masa pandemi covid-19 sedang melanda seluruh belahan dunia, namun dunia kecil kami, halaqah yang hanya berisi maksimal 15 orang anak yang rutin datang mengaji tetap eksis. Hasil pengamatan dan evaluasi yang mengontrol lima kemampuan dasar santri Rumbaqu yaitu pengenalan huruf, tajwid, mahraj, tartil dan menulis menunjukkan kemampuan baca tulis meningkat $65-80 \%$. Arange nilai ini berdasarkan pada bobot skala 50-65 dengan nilai Cukup; 66-75 dengan nilai Baik; 76-85 dengan nilai Baik Sekali; dan 86-99 dengan bobot nilai Excelence. Selain penilaian kuantitatif hasil pembelajaran, hal yang tidak bisa dipungkiri adalah kembalinya keceriaan anak-anak dalam belajar, ada semangat yang kembali bersinar, meskipun pergerakan tidak sebebas sebelumnya akibat pandemi covid-19.

\section{SIMPULAN DAN SARAN}

Hadirnya Rumbaqu menjadi oase tersendiri ditengah pandemi covid-19 bagi anak-anak komplek perumahan Islamic Centre Permai. Keberadaannya menjadi tempat untuk mendapatkan pendidikan huruf, tajwid, mahraj, tartil dan menulis. Secara kuantitatif rumbaqu berkontribusi positif dalam meningkatkan pengetahuan dan kemampuan anak dalam belajar Al-qur'an. Hal tersebut dapat dilihat pada hasil evaluasi yang menunjukkan nilai yang diproleh santri berkisar pada angka 60$85 \%$. Selain nilai kuaktitatif, hal yang tidak dapat dipungkiri adalah kembalinya keceriaan anak-anak dalam belajar.

Inisiasi sederhana ini semoga menjadi inspirasi bagi setiap orang yang membaca artikel ini. Terutama bagi mereka yang memiliki kemampuan untuk menyalurkan ilmunya (membaca dan menulis Al-Qur'an) demi terwujudnya generasi yang paham Al Qur'an sebagai tuntunan umat Islam. Ada banyak metode pembelajaran Al-qur'an seperti metode lqro, metode Al-baghdadiyah, metode Al- 
Baghdady, metode An-Nahdhiyah, dan metode Barqy. Dari empat metode yang populer kami hanya menggunakan dua metode karena kemampuan dan keterbatasan kami, sehingga pengasuh TPA atau dosen pengabdi dibidang ini dapat menambahkan dengan dua metode lainnya. Akhirul kalam billahi fii sabilil haq fastabiqul khaerat, wassalam

\section{UCAPAN TERIMAKASIH}

Tim pengabdi mengucapkan terimakasih kepada berbagai pihak yang telah mendorong selesainya program ini, terutama kepada seluruh warga Perum Islamic Centre yang telah bahu membahu membangun Rumbaqu. Terimakasih juga kami sampaikan kepada teman-teman pengasuh TPA se-Kota Palopo yang telah membantu kami dalam pengurusan legalitas Rumbaqu Ulil Albab pada Kantor Kementrian Agama Kota Palopo.

\section{DAFTAR RUJUKAN}

Anjarsari, R., Syahidin, S., \& Sumarna, E. (2017). Program Gerakan Cinta Alquran "Genta" Dalam Mengopimalkan Pendidikan Agama Islam Di Sekolah (Studi Deskriptif Di SMP Unggulan AlAmin Ngamprah). TARBAWY: Indonesian Journal of Islamic Education, 4(1), 57. https://doi.org/10.17509/t.v4i1.6992

Assingkily, M. S. (2019). Living Qur'an as a Model of Islamic Basic Education in the Industrial Era 4.0. Al Ibtida: Jurnal Pendidikan Guru MI, 6(1), 19. https://doi.org/10.24235/al.ibtida.snj.v6i1. 3876

Ath Thabrani, I. (2009). Adabul Mufrad (Indonesia). Darut Hadits.

Baharun, H. (2016). Pendidikan Anak dalam Keluarga; Telaah Epistemologis. Jurnal Pedidikan, 3(2), 96-107.

Cahyati, N., \& Kusumah, R. (2020). Peran Orang Tua Dalam Menerapkan Pembelajaran Di Rumah Saat Pandemi Covid 19. Jurnal Golden Age, 4(01), 4-6. https://doi.org/10.29408/jga.v4i01.2203

Iqromah, F. (2018). Identifikasi Kemampuan Anak Dalam Mengenal Huruf Hijaiyah Di Tk Se-Kecamatan Samigaluh Kulon Progo. Jurnal Pendidikan Anak Usia Dini, 1, 11-24.

Lubis, R. R., Mahrani, N., Margolang, D., \& Assingkily, M. S. (2020). Pembelajaran AlQur'an Era Covid-19: Tinjauan Metode dan Tujuannya pada Masyarakat di Kutacane Aceh Tenggara. Kuttab, 4(2). https://doi.org/10.30736/ktb.v4i2.275

Nurhidayah, N., Jabir, M., \& Rus'an, R. (2019). Studi Analisis Kemampuan Mengenal
Huruf Hijaiyah Pada Anak Usia Dini Melalui Bermain Puzzle Di Kelompok B Tk Al-Khairaat Kabonena Kota Palu. Ana' Bulava: Jurnal Pendidikan Anak, 1(1), 5362.

https://doi.org/10.24239/abulava.vol1.iss1 .4

Satrianingrum, A. P., \& Prasetyo, I. (2020). Persepsi Guru Dampak Pandemi Covid19 terhadap Pelaksanaan Pembelajaran Daring di PAUD. Jurnal Obsesi: Jurnal Pendidikan Anak Usia Dini, 5(1), 633. https://doi.org/10.31004/obsesi.v5i1.574

Ulfah, T. T., Assingkily, M. S., \& Kamala, I. (2019). Implementasi Metode Iqro' Dalam Pembelajaran Membaca Al-Qur'an. TA'DIBUNA: Jurnal Pendidikan Agama Islam, 2(2), 44. https://doi.org/10.30659/jpai.2.2.44-54 